Research Article

\title{
Identification of Key Indicators for Sustainable Construction Materials
}

\author{
Humphrey Danso (iD \\ Department of Construction and Wood Technology, University of Education Winneba, P.O. Box 1277, Kumasi, Ghana \\ Correspondence should be addressed to Humphrey Danso; dansohumphrey@yahoo.co.uk
}

Received 2 March 2018; Revised 26 March 2018; Accepted 10 April 2018; Published 26 April 2018

Academic Editor: Nadezda Stevulova

Copyright (C) 2018 Humphrey Danso. This is an open access article distributed under the Creative Commons Attribution License, which permits unrestricted use, distribution, and reproduction in any medium, provided the original work is properly cited.

\begin{abstract}
Studies on sustainable construction materials are on the rise with their environmental, social, and economic benefits. This study identifies the key indicators for measuring sustainable construction materials. The design used for the study was that of a survey which relied on a questionnaire with five-point Likert scale to generate data for the analysis. For this purpose, 25 indicators from the three dimensions (environmental, social, and economic) identified from the literature were presented to the respondents in a structured questionnaire, and responses were collected and analysed using SPSS. The study identified three key environmental indicators for measuring sustainable construction materials, and these indicators are human toxicity, climate change, and solid waste. Furthermore, adaptability, thermal comfort, local resources, and housing for all were identified as the four key social indicators for sustainable construction materials. In addition, maintenance cost, operational cost, initial cost, long-term savings, and life span were found to be the five key economic indicators for measuring sustainable construction materials. The study therefore suggests that these twelve indicators should be considered in future studies that seek to measure sustainable construction materials.
\end{abstract}

\section{Introduction}

The choice of construction materials has wide-reaching economic, environmental, and social consequence on any structure. The total cost of most structures depends greatly on the types of materials used. The energy consumption of any building has a significant relationship with the materials used for construction and the design of the building. Adaptability of some buildings by the society sometimes has bearing on the types of materials used. This therefore makes construction material an important factor in sustainable development. According to Ness et al. [1], sustainable development has been integrated into many aspects of the society in recent years. This has made the concept of sustainable development an important aspect of many industries worldwide [2]. According to Mailler [3], sustainability is an integrated concept, whereby environmental, social, and economic factors are interrelated. Sustainable development is a concept that is applicable in almost all fields of study and industry.
In the field of construction, sustainability is of great concern due to huge capital injunction and environmental factors coupled with societal adaptability. Construction materials and methodologies applied in building of structures have great influence in the sustainable development issues in the field of construction. Sustainable buildings take advantage of the natural resources available and depend on a "green" choice of materials [4]. According to Buildabroad [4], the availability of sustainable construction materials is on the rise, with new innovations and sourcing of materials that are not detrimental to the environment and are designed to enhance the energy efficiency of buildings. Sustainable construction materials are materials that are cost-effective and socially accepted and reduce negative environmental impacts, today and into the future during manufacturing and building structures. Peach [5] mentioned that sustainable construction materials include wool bricks, solar tiles, sustainable concrete, paper insulation, and triple-glazed windows. In low-income communities, earthbased technologies (such as rammed earth, compressed 
TABLE 1: Some studies on the properties of sustainable construction materials produced with waste.

\begin{tabular}{lc}
\hline Material & Reference \\
\hline Boron waste in soil bricks & {$[12]$} \\
Cassava peel in soil blocks & {$[13]$} \\
Coconut (coir) fibre in soil blocks & {$[14-17]$} \\
Coconut fibre in concrete & {$[18]$} \\
Waste paper in concrete & {$[19]$} \\
Waste paper in sandcrete blocks & {$[20]$} \\
Date palm in soil blocks & {$[21]$} \\
Flax (harakeke) in soil blocks & {$[22]$} \\
Hemp in concrete & {$[23]$} \\
Kenaf in soil blocks & {$[24]$} \\
Oil palm fibre in soil blocks & {$[25-27]$} \\
Pineapple leaves fibre in soil blocks & {$[28]$} \\
Plastic in soil blocks & {$[29-31]$} \\
Plastic in concrete & {$[32]$} \\
Sawdust in soil blocks & {$[33]$} \\
Scrap tire (crumb) rubber in soil blocks & {$[34,35]$} \\
Seaweed fibre in soil blocks & {$[36]$} \\
Sheep wool in soil blocks & {$[37,38]$} \\
Sisal fibre in soil blocks & {$[39]$} \\
Straw in soil blocks & {$[40-43]$} \\
Sugarcane bagasse ash in soil blocks & {$[44]$} \\
Sugarcane bagasse fibre in soil blocks & {$[14,25]$} \\
Waste phosphogypsum and natural & {$[45]$} \\
gypsum in soil blocks & {$[46]$} \\
Waste tea residue in soil bricks &
\end{tabular}

earth blocks, and stabilised soil blocks) are the commonly used sustainable construction materials.

A number of studies [6-11] have reviewed the volume of literature in earth-based sustainable construction materials. Danso et al. [6] reviewed the existing published works on the effect of stabilisers (fibres and binders) on technical performance of soil blocks or bricks using parameters such as compressive strength, water absorption, and flexural strength. Delgado and Guerrero [7] also reviewed the state of use of the earth building in Spain which presented research organisations, modern projects carried out, and the existing manufacturers for compressed earth blocks, and also examined a pair of nonregulatory guides that could act as national reference documents. Hejazi et al. [8] reviewed the history, benefits, application, and possible executive problems of using different types of natural and/or synthetic fibres in soil reinforcement. Maniatidis and Walker [10] made a review of rammed earth construction by considering national codes, materials, structural design, construction, quality control, foundations, and maintenance. PachecoTorgal and Jalali [11] also reviewed some of the environmental benefits associated with earth construction including an overview about its past and present. They also included a review of economic issues, nonrenewable resource consumption, waste generation, energy consumption, carbon dioxide emissions, and indoor air quality.

The use of waste in producing sustainable construction materials is generating research interest in the last decade. Studies have investigated the properties of sustainable construction materials produced with waste in concrete or blocks. Table 1 outlines some of these studies and the types of sustainable construction materials they investigated.

It can be seen from Table 1 that some studies have investigated the properties of sustainable concrete with waste materials such as paper, plastic, and natural fibres. Earthbased construction materials have rather seen a large volume of research works. While rammed earth has also seen a number of studies into its properties, earth/soil blocks/bricks have recorded a massive investigation with different waste materials such as natural fibres, sawdust, scrap tire rubber, plastics, and animal wool fibres. All these studies contribute to the literature on sustainable construction materials.

Identifying and measuring the indicators for sustainable construction materials is relevant in placing construction material studies in the context of sustainable development. Danso [2] reviewed the general and relevant available indicators for measuring sustainable construction materials. However, there is lack of information on the most important sustainable indicators in relation with construction materials. This paper therefore identifies the key indicators for measuring sustainable construction materials.

\section{Methodology}

The design used for this study was that of a survey which relied on a questionnaire to generate data for the analysis. The questionnaire was developed, pretested to a sample of three experts in construction materials, and then modifications were made to obtain a more efficient instrument. A five-point Likert scale was used to measure the key indicators for sustainable construction materials. The Likert scale ranged from unimportant (1) to very important (5). Three main dimensions used are environmental, social, and economic. The environmental dimension consisted of eleven indicators, social dimension had eight indicators, and economic dimension had six indicators, making a total of 25 indicators. These indicators were adopted from the previous study [2] which reviewed the general and relevant available indicators for measuring sustainable construction materials. The indicators under their various dimensions are shown in Figure 1 which presents the hierarchical structure for construction material sustainability assessment. The questionnaire also asked the respondents to add any indicators they consider important and make any suggestions.

The population for the study was the professionals from the construction industry and academics who have researched and published in the area of construction and building materials. A purposive sampling technique was adopted to select the professional for data collection. The professionals were identified through their published materials (articles, books, and reports), and their email addresses noted. The questionnaire was designed with Adobe Acrobat Professional version 11, which made it easy to be emailed as an attachment to the respondents. In the email, the respondents were told to download, click preferred responses, save, and return by email. The questionnaire was administered to the construction professionals through their email addresses. After a month, a reminder was sent to those who have not responded. It must be noted that few emails 

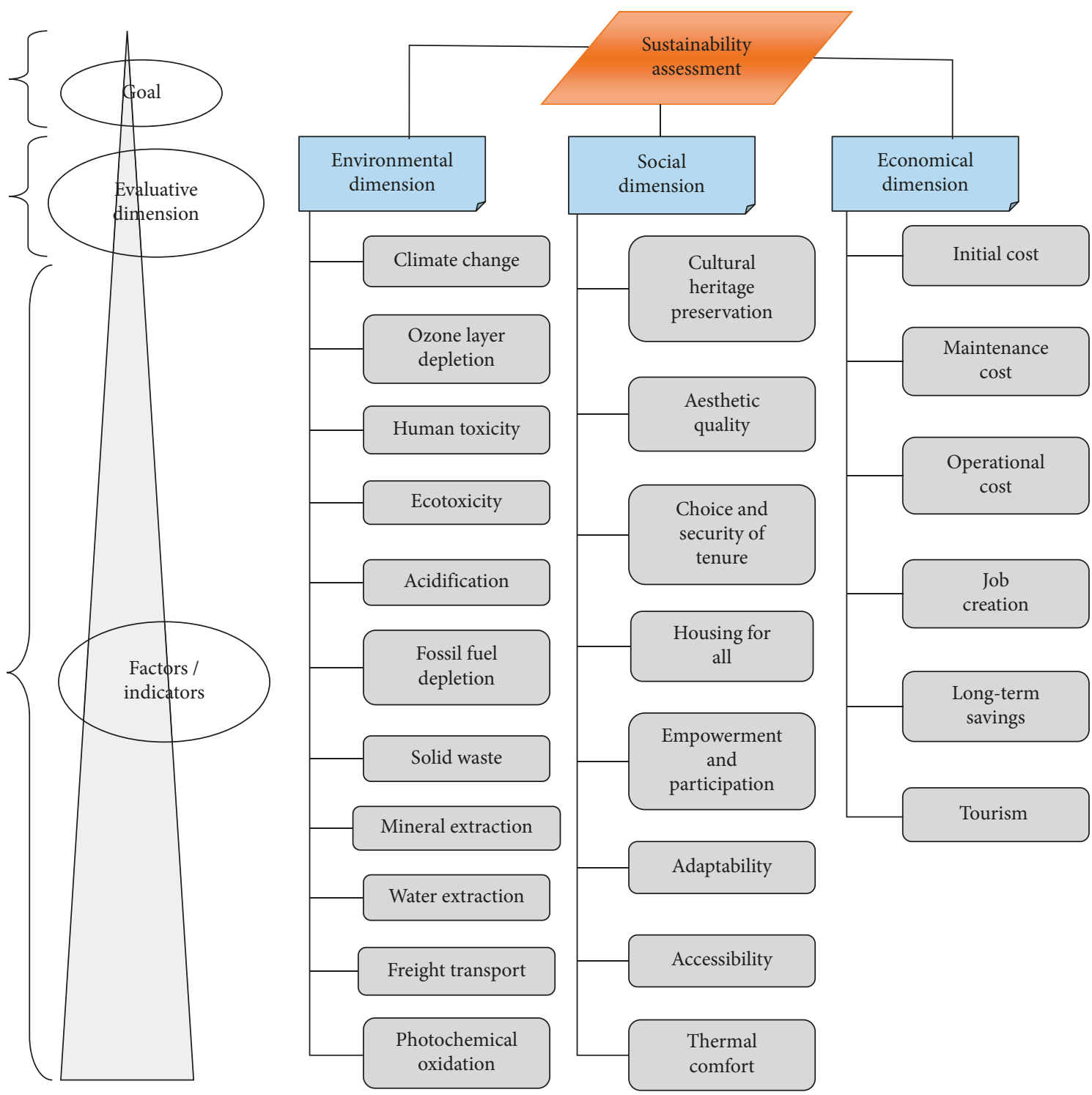

FIgURE 1: Hierarchical structure for construction material sustainability assessment [2].

were returned as error which might be due to invalid and wrong addresses.

The completed and returned questionnaires were downloaded, printed, and coded. The data obtained were analysed using the statistical package for social sciences (SPSS) version 22. The data from the questionnaire were inputted into SPSS and analysed by the use of descriptive statistics for obtaining the mean and standard deviation. In determining the key indicators for each dimension, a hypothesized mean of 4.000 and above was set as a critical cutoff point. It means that any indicator that recorded a mean of 4.000 or above was considered a key indicator, which the study identified as measuring sustainable construction materials. This represented the respondents' choice of indicators ranked between important and very important.

\section{Results and Discussion}

Out of the 115 questionnaires administered, 45 usable questionnaires were obtained, representing 39\% response rate. Construct validity was also ensured by critically developing the indicators within an established theoretical framework. The Cronbach alpha reliability test for the items was above the recommended 0.7 [47]. From Table 2, all of the constructs have item loadings higher than the recommended 0.70. Data were analysed using descriptive analysis. The responses of the respondents are presented under three dimensions: (1) environmental, (2) social, and (3) economic.

3.1. Key Environmental Indicators. Table 3 presents the analysis of the environmental indicators of sustainable construction materials. The descriptive analysis shows that three items recorded mean values of 4.000 or more, which implies that the respondents rated the items between important and very important. The first ranked indicator for the environmental dimension is "human toxicity" with a mean value of 4.267. The following two indicators are "climate change" and "solid waste," both with a mean value of 4.000 . The 
TABLE 2: Item loading and construct reliability.

\begin{tabular}{|c|c|c|c|c|}
\hline Dimension & Code & Indicators & $\begin{array}{l}\text { Number } \\
\text { of items }\end{array}$ & $\begin{array}{c}\text { Cronbach } \\
\text { alpha }\end{array}$ \\
\hline \multirow{11}{*}{ Environmental } & EN1 & Climate change & \multirow{11}{*}{11} & \multirow{11}{*}{0.734} \\
\hline & EN2 & $\begin{array}{l}\text { Ozone layer } \\
\text { depletion }\end{array}$ & & \\
\hline & EN3 & Human toxicity & & \\
\hline & EN4 & Ecotoxicity & & \\
\hline & EN5 & $\begin{array}{l}\text { Acidification } \\
\text { (acid deposit) }\end{array}$ & & \\
\hline & EN6 & $\begin{array}{l}\text { Fossil fuel } \\
\text { depletion }\end{array}$ & & \\
\hline & EN7 & Solid waste & & \\
\hline & EN8 & $\begin{array}{c}\text { Mineral } \\
\text { extraction }\end{array}$ & & \\
\hline & EN9 & Water extraction & & \\
\hline & EN10 & Freight transport & & \\
\hline & EN11 & $\begin{array}{l}\text { Photochemical } \\
\text { oxidation }\end{array}$ & & \\
\hline \multirow{8}{*}{ Social } & SO1 & $\begin{array}{c}\text { Cultural heritage } \\
\text { preservation }\end{array}$ & \multirow{8}{*}{8} & \multirow{8}{*}{0.875} \\
\hline & $\mathrm{SO} 2$ & Aesthetic quality & & \\
\hline & SO3 & $\begin{array}{c}\text { Choice and } \\
\text { security of tenure }\end{array}$ & & \\
\hline & $\mathrm{SO} 4$ & Housing for all & & \\
\hline & SO5 & $\begin{array}{l}\text { Empowerment } \\
\text { and participation }\end{array}$ & & \\
\hline & SO6 & Adaptability & & \\
\hline & $\mathrm{SO} 7$ & Accessibility & & \\
\hline & $\mathrm{SO} 8$ & Thermal comfort & & \\
\hline \multirow{6}{*}{ Economic } & $\mathrm{EC} 1$ & Initial cost & \multirow{6}{*}{6} & \multirow{6}{*}{0.820} \\
\hline & EC2 & Maintenance cost & & \\
\hline & EC3 & Operational cost & & \\
\hline & $\mathrm{EC} 4$ & Job creation & & \\
\hline & EC5 & $\begin{array}{l}\text { Long-term } \\
\text { savings }\end{array}$ & & \\
\hline & EC6 & Tourism & & \\
\hline
\end{tabular}

TABle 3: Descriptive statistics on environmental indicators $(n=45)$.

\begin{tabular}{lccc}
\hline Indicator & $\bar{x}$ & $\sigma$ & $R$ \\
\hline Human toxicity & $4.267^{*}$ & 1.009 & 1 \\
Climate change & $4.000^{*}$ & 1.108 & 2 \\
Solid waste & $4.000^{*}$ & 0.739 & 2 \\
Ecotoxicity & 3.933 & 0.780 & 3 \\
Water extraction & 3.867 & 0.815 & 4 \\
Photochemical oxidation & 3.800 & 1.057 & 5 \\
Acidification & 3.667 & 1.023 & 6 \\
Fossil fuel depletion & 3.667 & 1.023 & 6 \\
Ozone layer depletion & 3.667 & 1.087 & 6 \\
Mineral extraction & 3.600 & 0.963 & 7 \\
Freight transport & 3.000 & 0.826 & 8 \\
\hline
\end{tabular}

${ }^{*}$ Key indicator, mean $\geq 4.000$.

other environmental indicators (ecotoxicity, water extraction, photochemical oxidation, acidification, fossil fuel depletion, ozone layer depletion, mineral extraction, and freight transport) recorded values less than the hypothesized mean.

From the results, it can be seen that three indicators were identified as the key environmental sustainable construction materials. These indicators are human toxicity, climate change, and solid waste. Human toxicity aims to quantify the degree to which a particular substance causes damage to living organisms. Assessments of toxicity are based on guidelines for tolerable concentrations in air and water, tolerable daily intake, and acceptable daily intake for human toxicity [48]. Many of the chemicals used in the society have not undergone a risk assessment, and assessment techniques are still developing, something that manufacturers of construction products should also be aware of [48]. Issues relating to toxicity generate much debate in the construction industry, especially manufacturing of construction materials and their disposal after demolition. Users of construction materials should carefully review the material supplier's guidance and note any relevant regulations, codes, and standards appropriately. They should also consider the context and application within which the materials are to be used to ensure that industry-specific regulations or standards are complied with.

Climate change refers to the change in global temperature caused by the greenhouse effect by the release of "greenhouse gases" such as carbon dioxide by human activity. There is now scientific consensus that the increase in these emissions is having a noticeable effect on climate. Raised global temperature is expected to cause climatic disturbance, desertification, rising sea levels, and spread of disease [49]. Embodied carbon is the carbon dioxide $\left(\mathrm{CO}_{2}\right)$ or greenhouse gas (GHG) emissions associated with the manufacture and use of a product or service. For construction products, this means the $\mathrm{CO}_{2}$ or $\mathrm{GHG}$ emissions associated with extraction, manufacturing, transporting, installing, maintaining, and disposing of construction materials and products [48].

Solid waste represents the environmental issues associated with the loss of resource implied by the final disposal of waste, and any waste that is disposed of in landfill or incinerated without energy recovery. The characterisation methodologies, for example, the Dutch EcoIndicator30 and the Swiss Ecopoints31, and the characterisation factors are based on the mass of solid waste [49]. Solid waste generated by construction materials is huge, from manufacturing of the materials, application of the materials, and disposal of the demolished structures.

3.2. Key Social Indicators. The analysis of the social indicators of sustainable construction materials can be seen in Table 4 . The result indicates that four indicators were rated by the respondents as the key indicators within the theoretical mean of 4.000. "Adaptability" was the first ranked indicator with a mean value of 4.133 . The second ranked indicator was "thermal comfort" with a mean value of 4.067. The next ranked indicators were "local resources" and "housing for all," both with a mean value of 4.000. Indicators such as cultural heritage, social value, choice and security of tenure, accessibility, empowerment and participation, and aesthetic quality had values less than the hypothetical mean.

Adaptable buildings are defined as "dynamic systems that carry the capacity to accommodate a set of evolving demands 
TABLE 4: Descriptive statistics on social indicators $(n=45)$.

\begin{tabular}{lccc}
\hline Indicator & $\bar{x}$ & $\sigma$ & $R$ \\
\hline Adaptability & $4.133^{*}$ & 0.815 & 1 \\
Thermal comfort & $4.067^{*}$ & 0.939 & 2 \\
Local resources & $4.000^{*}$ & 0.977 & 3 \\
Housing for all & $4.000^{*}$ & 1.108 & 3 \\
Cultural heritage & 3.867 & 1.217 & 4 \\
Social value & 3.733 & 0.688 & 5 \\
Choice and security of tenure & 3.733 & 0.939 & 5 \\
Accessibility & 3.600 & 1.095 & 6 \\
Empowerment and participation & 3.600 & 1.156 & 6 \\
Aesthetic quality & 3.533 & 0.815 & 7 \\
\hline
\end{tabular}

${ }^{*}$ Key indicator, mean $\geq 4.000$.

regarding space, function, and components [50]". To ensure sustainability, building materials must build in adaptability to both its existing and new buildings. Buildings are more likely to be occupied and reused if they can be easily adapted to meet changing needs [51]. Buildings which are unable to adapt with such changing needs will become obsolete or require substantial refurbishment or demolition, where neither option may create a sustainable built environment [52].

Thermal comfort is the condition of mind which expresses satisfaction with the thermal environment [53], that is, the condition when someone is not feeling either too hot or too cold [54]. Building materials contribute greatly to thermal comfort of any structure. Adaptive thermal comfort broadens understanding of the human comfort zone by taking into account the ways that people's perceptions of their environment change based on seasonal expectations of temperature and humidity [55]. It is an undeniable fact (especially in warm climate areas) that houses built with local materials have cool room temperature particularly with houses built with soil or earth and thatches [56]. The consideration of thermal comforts is therefore important when selecting construction materials.

Local resources (materials) are usually available and affordable in most localities. Nature has provided mankind with some wonderful materials to build houses, and these materials require little processing or transporting and the costs are low [57]. It is important to identify and use locally manufactured and available materials (sand, stones, grass, thatches, clay, timber, clay bricks, and clay blocks) in providing houses especially in the developing countries in order to meet their housing demand [56].

"Housing for all" is a concept that describes the situation of ensuring that housing becomes affordable and available to every individual. Housing for all is therefore associated with affordable or low-cost housing. UN Habitat [58] defined affordable housing as a house that is adequate in quality and location and does not cost such that it prohibits its occupants from meeting other living costs and threatens their enjoyment of basic human rights. Low-cost housing on the other hand is a housing concept whose total cost for purchase or rent is deemed affordable for those in the median income bracket $[59,60]$. The factors that contribute to housing for all include cost of materials, cost of labour, and cost of land, among others. The cost of construction materials constitutes between $60 \%$ and $70 \%$ of the cost of a building in developing
Table 5: Descriptive statistics on economic indicators $(n=45)$.

\begin{tabular}{lccc}
\hline Indicator & $\bar{x}$ & $\sigma$ & $R$ \\
\hline Maintenance cost & $4.400^{*}$ & 0.889 & 1 \\
Operational cost & $4.400^{*}$ & 0.889 & 1 \\
Initial cost & $4.400^{*}$ & 0.889 & 1 \\
Long-term savings & $4.333^{*}$ & 0.879 & 2 \\
Life span & $4.067^{*}$ & 1.136 & 3 \\
Job creation & 3.667 & 1.087 & 4 \\
Tourism & 2.800 & 0.919 & 5 \\
\hline
\end{tabular}

${ }^{*}$ Key indicator, mean $\geq 4.000$.

countries [61]. Therefore, reduction of the material cost will invariably help in promoting housing for all.

3.3. Key Economic Indicators. Descriptive analysis of the economic indicators of sustainable construction materials is shown in Table 5. Five indicators were identified by the respondents as key economic factors of sustainable construction materials. These are maintenance cost, operational cost, initial cost, long-term savings, and life span, which recorded a mean value above 4.000 by the respondents. Indicators such as job creation and tourism obtained mean values below the hypothesized mean.

The maintenance cost of building components is the cost involved in the process of sustaining the performance of a building in accordance with the documented design and the operational needs. This process involves a set of activities that help in sustaining a building's components. Sahely et al. [62] opined that economic indicators such as operation and maintenance costs continue to play an important role in decision making as part of a larger set of indicators. Maintenance cost involves the cost of caring for the components of building to ensure reliability and prevention of failure.

The operational cost is the cost incurred in the day-today running or operation of the building. The operational cost includes mortgage payments, building insurance, taxes, maintenance and repair cost, and general and administrative expenses [54].

Initial costs are the costs that are incurred during the design and construction process. The initial cost of construction project includes the cost at the following stages of construction: planning, preliminary, design, and construction. The initial cost includes the cost of acquiring land and cost of materials for constructing the structures.

Long-term savings is critical in reducing the running cost of any structure. Construction materials and components with a long-term savings and low-maintenance effort reduce investments for maintenance, replacement, and renovation. While some sustainable materials may require greater upfront costs, they bring with them long-term savings due to reduced energy and transportation costs, as well as being beneficial for the environment in the long term [4].

\section{Summary and Conclusion}

The aim of this paper was to identify the key indicators for measuring sustainable construction materials. This study 
was based on the three main dimensions of sustainable development, which are environmental, social, and economic. The study adopted 25 indicators from the literature out of which the respondents identified twelve (12) as key indicators for measuring sustainable construction materials. These include three key environmental indicators for measuring sustainable construction materials, which are human toxicity, climate change, and solid waste. Furthermore, adaptability, thermal comfort, local resources, and housing for all were identified as the four key social indicators for sustainable construction materials. In addition, maintenance cost, operational cost, initial cost, long-term savings, and life span were found to be the five key economic indicators for measuring sustainable construction materials. The study therefore suggests that these twelve indicators should be considered in future for any study that seeks to measure sustainable construction materials.

\section{Data Availability}

The data used to support the findings of this study are available from the corresponding author upon request.

\section{Conflicts of Interest}

The authors declare that they have no conflicts of interest.

\section{References}

[1] B. Ness, E. Urbel-Piirsalu, S. Anderberg, and L. Olsson, "Categorising tools for sustainability assessment," Ecological Economics, vol. 60, no. 3, pp. 498-508, 2007.

[2] H. Danso, "Dimensions and indicators for sustainable construction materials: a review," Research and Development in Material Science, vol. 3, no. 4, pp. 1-9, 2018.

[3] M. Mailler, "Sustainability assessment of an IAIA educational \& networking forum," in Proceedings of 28th Annual Conference of the International Association for Impact Assessment, Perth, Australia, May 2008.

[4] Buildabroad, Sustainable Materials: The Backbone of Any Sustainable Building Project, 2017, https://buildabroad.org/ 2017/08/15/sustainable-materials.

[5] J. Peach, Five Sustainable Building Materials that Could Transform Construction, 2010, http://thisbigcity.net/fivesustainable-building-materials-that-could-transformconstruction.

[6] H. Danso, B. Martinson, M. Ali, and C. Mant, "Performance characteristics of enhanced soil blocks: a quantitative review," Building Research and Information, vol. 43, no. 2, pp. 253-262, 2015.

[7] M. C. J. Delgado and I. C. Guerrero, "Earth building in Spain," Construction and Building Materials, vol. 20, no. 9, pp. 679690, 2006.

[8] S. M. Hejazi, M. Sheikhzadeh, S. M. Abtahi, and A. Zadhoush, "A simple review of soil reinforcement by using natural and synthetic fibres," Construction and Building Materials, vol. 30, pp. 100-116, 2012.

[9] J. M. Khatib, Sustainability of Construction Materials, Woodhead Publishing, CRC Press, Cambridge, UK, 2009.

[10] V. Maniatidis and P. Walker, A Review of Rammed Earth Construction, University of Bath, Bath, UK, 2003.
[11] F. Pacheco-Torgal and S. Jalali, "Earth construction: lessons from the past for future eco-efficient construction," Construction and Building Materials, vol. 29, pp. 512-519, 2012.

[12] T. Kavas, "Use of boron waste as a fluxing agent in production of red mud brick," Building and Environment, vol. 41, no. 12, pp. 1779-1783, 2006.

[13] M. C. N. Villamizar, V. S. Araque, C. A. R. Reyes, and R. S. Silva, "Effect of the addition of coal-ash and cassava peels on the engineering properties of compressed earth blocks," Construction and Building Materials, vol. 36, pp. 276-286, 2012.

[14] H. Danso, B. Martinson, M. Ali, and J. B. Williams, "Effect of sugarcane bagasse fibre on the strength properties of soil blocks," in Proceedings of 1st International Conference on Biobased Building Materials, Clermont-Ferrand, France, June 2015.

[15] B. Gaw and S. Zamora, Soil Reinforcement with Natural Fibers for Low-Income Housing Communities, MSc thesis, Worcester Polytechnic Institute, Worcester, MA, USA, 2011.

[16] J. I. Aguwa, "Study of coir reinforced laterite blocks for buildings," Journal of Civil Engineering and Construction Technology, vol. 4, pp. 110-115, 2013.

[17] M. G. Sreekumar and D. G. Nair, "Stabilized lateritic blocks reinforced with fibrous coir wastes," International Journal of Sustainable Construction Engineering and Technology, vol. 4, pp. 23-32, 2013.

[18] P. P. Yalley, Use of Waste and Low Energy Materials in Construction, Lambert Academic Publishing, Saarbrücken, Germany, 2012.

[19] I. I. Akinwumi, O. M. Olatunbosun, O. M. Olofinnade, and P. O. Awoyera, "Structural evaluation of lightweight concrete produced using waste newspaper and office paper," Civil and Environmental Research, vol. 6, pp. 160-167, 2014.

[20] H. Yun, H. Jung, and C. Choi, "Mechanical properties of papercrete containing waste paper," in Proceedings of 18th International Conference on Composite Materials, Jeju Province, Republic of Korea, August 2011.

[21] B. Taallah, A. Guettala, S. Guettala, and A. Kriker, "Mechanical properties and hygroscopicity behavior of compressed earth block filled by date palm fibers," Construction and Building Materials, vol. 59, pp. 161-168, 2014.

[22] T. M. Le and K. L. Pickering, "The potential of harakeke fibre as reinforcement in polymer matrix composites including modelling of long harakeke fibre composite strength," Composites Part A: Applied Science and Manufacturing, vol. 76, pp. 44-53, 2015.

[23] S. Elfordy, F. Lucas, F. Tancret, Y. Scudeller, and L. Goudet, "Mechanical and thermal properties of lime and hemp concrete ("hempcrete") manufactured by a projection process," Construction and Building Materials, vol. 22, no. 10, pp. 2116-2123, 2008.

[24] Y. Millogo, J. E. Aubert, E. Hamard, and J. C. Morel, "How properties of kenaf fibers from Burkina Faso contribute to the reinforcement of earth blocks," Materials, vol. 8, no. 5, pp. 2332-2345, 2015.

[25] H. Danso, D. B. Martinson, M. Ali, and J. Williams, "Effect of fibre aspect ratio on mechanical properties of soil building blocks," Construction and Building Materials, vol. 83, pp. 314-319, 2015.

[26] S. Ismail and Z. Yaacob, "Properties of laterite brick reinforced with oil palm empty fruit bunch fibres," Pertanika Journal of Science and Technology, vol. 19, pp. 33-43, 2011.

[27] S. M. Marandi, M. H. Bagheripour, R. Rahgozar, and H. Zare, "Strength and ductility of randomly distributed palm fibers 
reinforced silty-sand soils," American Journal of Applied Sciences, vol. 5, no. 3, pp. 209-220, 2008.

[28] C. M. Chan, "Effect of natural fibers inclusion in clay bricks: physico-mechanical properties," International Journal of Civil and Environmental Engineering, vol. 3, pp. 51-57, 2011.

[29] P. P. Yalley and A. S. K. Kwan, "Use of waste and low energy materials in building block construction," in Proceedings of 25th Conference on Passive and Low Energy Architecture (PLEA), Dublin, Ireland, June 2008.

[30] C. K. Subramaniaprasad, B. M. Abraham, and E. K. K. Nambiar, "Sorption characteristics of stabilised soil blocks embedded with waste plastic fibres," Construction and Building Materials, vol. 63, pp. 25-32, 2014.

[31] J. Cid-Falceto, F. R. Mazarrón, and I. Cañas, "Assessment of compressed earth blocks made in Spain: international durability tests," Construction and Building Materials, vol. 37, pp. 738-745, 2012.

[32] M. Raghatate Atul, "Use of plastic in a concrete to improve its properties," International Journal of Advanced Engineering Research and Studies, vol. 1, pp. 109-111, 2012.

[33] B. R. T. Vilane, "Assessment of stabilisation of adobes by confined compression tests," Biosystems Engineering, vol. 106, no. 4, pp. 551-558, 2010.

[34] S. Akbulut, S. Arasan, and E. Kalkan, "Modification of clayey soils using scrap tire rubber and synthetic fibers," Applied Clay Science, vol. 38, no. 1-2, pp. 23-32, 2007.

[35] P. Turgut and B. Yesilata, "Physico-mechanical and thermal performances of newly developed rubber-added bricks," Energy and Buildings, vol. 40, no. 5, pp. 679-688, 2008.

[36] M. Achenza and L. Fenu, "On earth stabilization with natural polymers for earth masonry construction," Materials and Structures, vol. 39, no. 1, pp. 21-27, 2006.

[37] F. Aymerich, L. Fenu, and P. Meloni, "Effect of reinforcing wool fibres on fracture and energy absorption properties of an earthen material," Construction and Building Materials, vol. 27, no. 1, pp. 66-72, 2012.

[38] C. Galán-Marín, C. Rivera-Gómez, and J. Petric, "Clay-based composite stabilised with natural polymer and fibre," Construction and Building Materials, vol. 24, no. 8, pp. 1462-1468, 2010.

[39] S. S. Namango and D. S. Madara, "Compressed earth blocks reinforced with sisal fibres," Journal of Agricultural Pure Applied Science and Technology, vol. 19, pp. 10-22, 2014.

[40] W. Quagliarini and S. Lenci, "The influence of natural stabilisers and natural fibres on the mechanical properties of ancient Roman adobe bricks," Journal of Cultural Heritage, vol. 11, no. 3, pp. 309-314, 2010.

[41] S. Yetgin, O. Cavdar, and A. Cavdar, "The effects of the fiber contents on the mechanic properties of the adobes," Construction and Building Materials, vol. 22, no. 3, pp. 222-227, 2008.

[42] F. Parisi, D. Asprone, L. Fenu, and A. Prota, "Experimental characterization of Italian composite adobe bricks reinforced with straw fibers," Composite Structures, vol. 122, pp. 300-307, 2015.

[43] A. Laborel-Préneron, J.-E. Aubert, C. Magniont, P. Maillard, and C. Poirier, "Effect of plant aggregates on mechanical properties of earth bricks," American Society of Civil Engineers, vol. 29, no. 12, p. 04017244, 2017.

[44] S. A. Lima, H. Varum, A. Sales, and V. F. Neto, "Analysis of the mechanical properties of compressed earth block masonry using the sugarcane bagasse ash," Construction and Building Materials, vol. 35, pp. 829-837, 2012.

[45] N. Degirmenci, "The using of waste phosphogypsum and natural gypsum in adobe stabilization," Construction and Building Materials, vol. 22, no. 6, pp. 1220-1224, 2008.
[46] I. Demir, "An investigation on the production of construction brick with processed waste tea," Building and Environment, vol. 41, no. 9, pp. 1274-1278, 2006.

[47] D. Straub, M. Boudreau, and D. Gefen, "Validation guidelines for IS positivist research," Communications of the Association for Information Systems, vol. 13, pp. 380-427, 2004.

[48] J. Anderson and J. Thornback, A Guide to Understanding the Embodied Impacts of Construction Products, Construction Products Association, London, UK, 2012.

[49] BRE, Methodology for Environmental Profiles of Construction Products: Product Category Rules for Type III Environmental Product Declaration of Construction Products (Draft), 2007.

[50] Adaptable Futures, Homepage of adaptable futures, 2012, http://www.adaptablefutures.com.

[51] E. Annex, Buildings-Adaptability, Durability and Materials, 2015, http://democracy.york.gov.uk/documents/s4858/Annex \%20E\%20Sustainable\%20Development.pdf.

[52] A. Manewa, M. Siriwardena, A. Ross, and U. Madanayake, "Adaptable Buildings for sustainable built environment," Built Environment Project and Asset Management, vol. 6, no. 2, pp. 139-158, 2016.

[53] BS EN ISO 7730, Ergonomics of the thermal environment, Analytical determination and interpretation of thermal comfort using calculation of the PMV and PPD indices and local thermal comfort criteria, 2005.

[54] Designing Buildings Wiki, Thermal comfort in buildings, 2016, https://www.designingbuildings.co.uk/wiki/Thermal_comfort_ in_buildings.

[55] A. Ward, J. Boehland, and N. Malin, Thermal Comfort and Building Management, BuildingGreen, 2018, http://fmlink. com/articles/thermal-comfort-and-building-management.

[56] H. Danso, "Building houses with locally available materials in Ghana: benefits and problems," International Journal of Science and Technology, vol. 2, no. 2, pp. 225-231, 2013.

[57] GreenHomeBuilding, Use Local Materials, 2016, http://www. greenhomebuilding.com/localmaterials.htm.

[58] UN Habitat, Affordable land and housing in Africa United Nations Human Settlement Programme, 2011.

[59] B. Bhatta, "Analysis of urban growth and sprawl from remote sensing data," in Advances in Geographic Information Science, pp. 23-42, Springer, Berlin, Germany, 2010.

[60] H. Danso, Use of agricultural waste fibres as enhancement of soil blocks for low-cost housing in Ghana, Ph.D. thesis, School of Civil Engineering and Surveying, University of Portsmouth, 2015.

[61] H. Danso and D. Menu, "High cost of materials and land acquisition problems in the construction industry in Ghana," International Journal of Research in Engineering and Applied Sciences, vol. 3, no. 3, pp. 18-33, 2013.

[62] H. R. Sahely, C. A. Kennedy, and B. J. Adams, "Developing sustainability criteria for urban infrastructure systems," $\mathrm{Ca}$ nadian Journal of Civil Engineering, vol. 32, no. 1, pp. 72-85, 2005. 


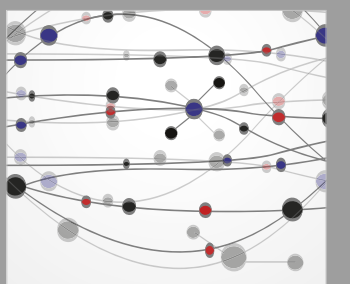

The Scientific World Journal
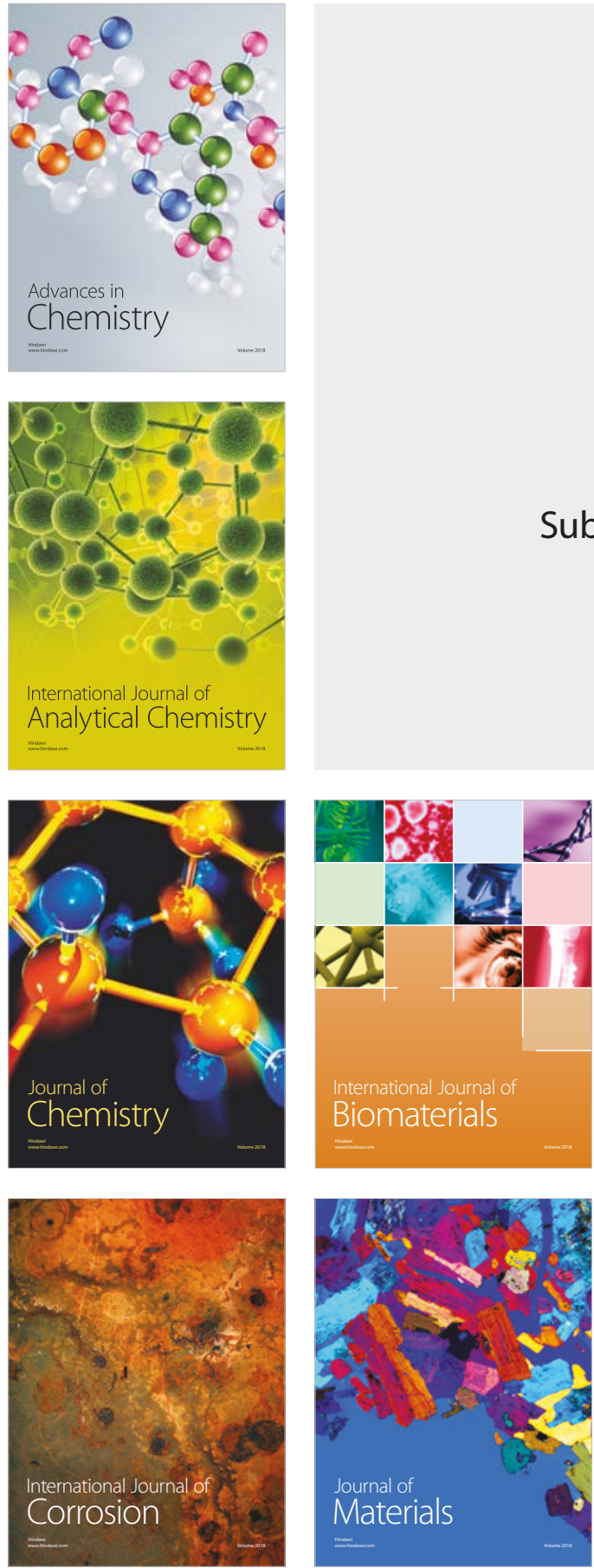

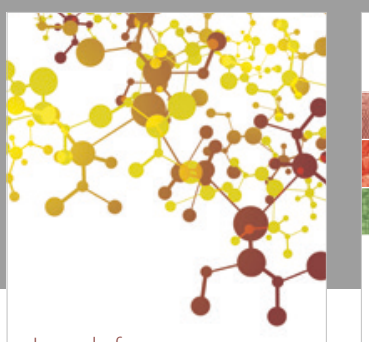

Journal of

Applied Chemistry
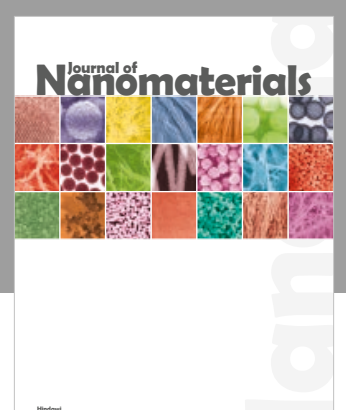

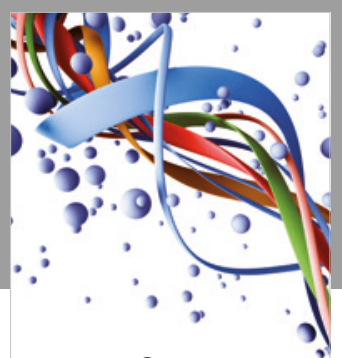

Scientifica

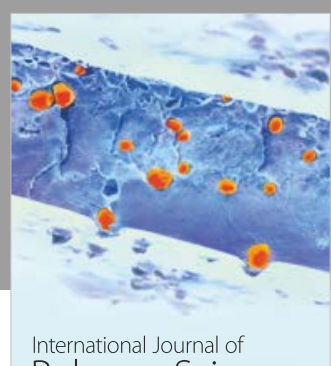

Polymer Science

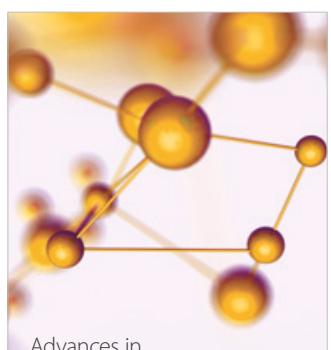

Physical Chemistry
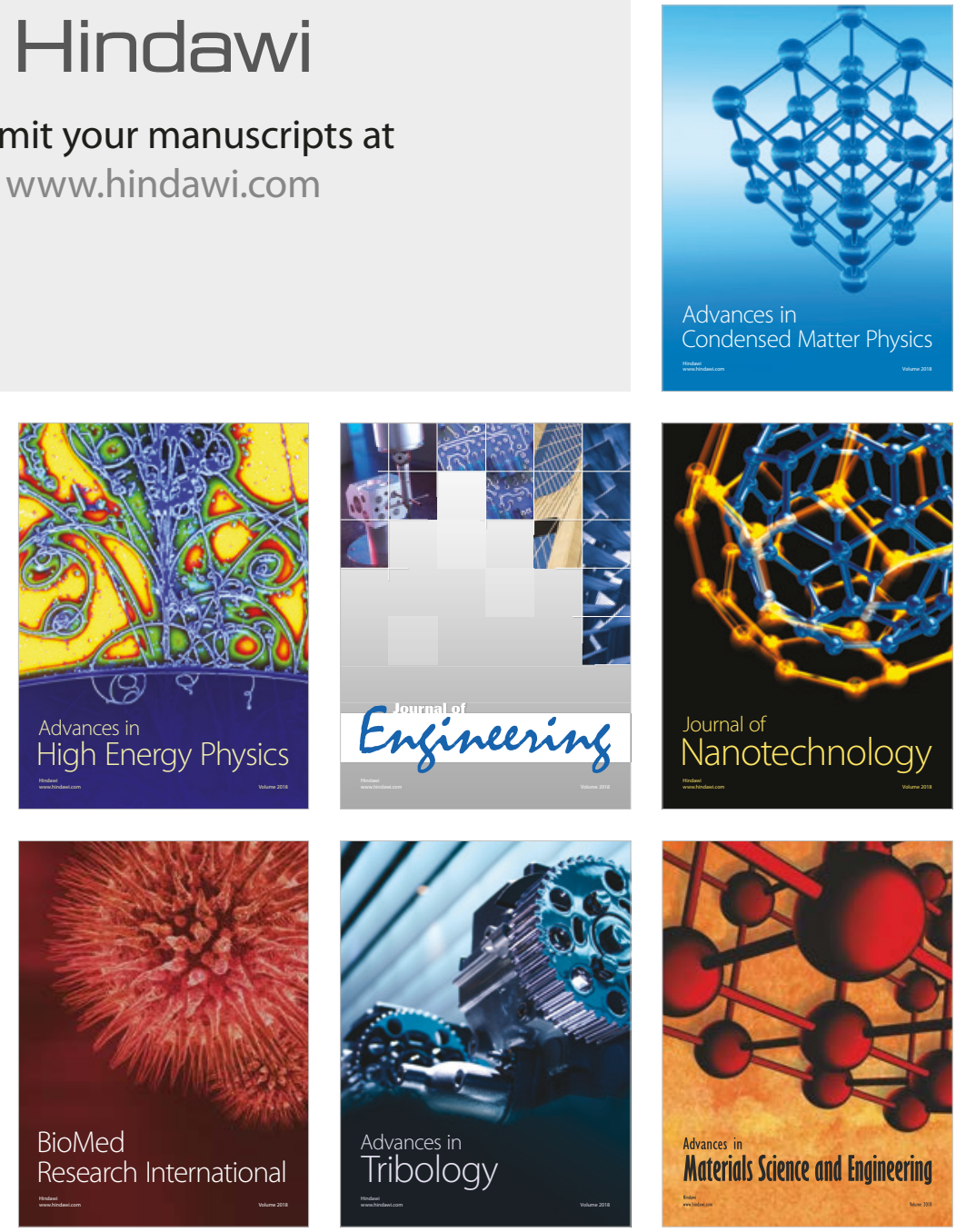